JEL Classification: D21, D64, F23, G30, L21, M14, P52

Keywords: corporate philanthropy, corporate giving, sponsoring, survey data, economic transformation, tax treatment

\title{
Corporate Philanthropy in the Czech and Slovak Republics
}

\author{
Jan HANOUSEK - CERGE-EI, Charles University and the Academy of Sciences, Prague; Anglo- \\ -American University, Prague; The William Davidson Institute, Michigan; and \\ CEPR, London \\ Evžen KOČENDA - CERGE-EI, Charles University and the Academy of Sciences, Prague; Anglo- \\ -American University, Prague; CESifo, Munich; OEl, Regensburg; William \\ Davidson Institute, Michigan; CEPR, London; and the Euro Area Business \\ Cycle Network (evzen.kocenda@cerge-ei.cz) \\ Katarína SVÍTKOVÁ - Anglo-American University, Prague; CERGE-EI, Charles University and \\ the Academy of Sciences, Prague- corresponding author
}

\section{Abstract}

We analyze corporate charitable behavior and the motivation for it in the Czech and Slovak Republics. In our quantitative study we distinguish different channels of support: sponsoring and giving. We do not find evidence supporting the usual claim that foreign firms give more than domestic ones, but the results suggest that foreign firms give to maximize profits more often than domestic ones. The Czech Republic leads in giving over Slovakia, where the importance of large and international firms is higher. No significant decline in giving is found in Slovakia after changes in its tax legislation made giving more expensive.

\section{Introduction}

Corporate social responsibility has recently become an important topic of debate and research focusing on the social behavior of firms. Corporate giving as an important aspect of corporate social responsibility has also gained significant attention in recent decades in mature economies, as the levels of giving in mature economies are significant and therefore represent a major source of funding for nonprofit organizations. Emerging markets have a relatively small amount of corporate giving, and therefore not much research on the topic has been performed for emerging economies. This is especially the case when one considers quantitative empirical research. ${ }^{1}$ In this paper we aim to fill this gap in the empirical literature by providing a quantitative analysis of corporate philanthropy - considered as a still-important component of corporate social responsibility - in two post-transformation European economies.

The motives for philanthropic firm behavior are not necessarily purely altruistic, for they can have very rational roots. In addition to theoretical considerations, there exist empirical studies examining the link between the tax rate and corporate philanthropy. For example, in a U.S. study Navarro (1988) found a very small negative effect of the tax rate, a finding that supports the hypothesis that giving is a form of advertising motivated by the maximization of profit. Further, Boatsman and Gupta

\footnotetext{
"We would like to thank Richard Steinberg, CORE Conference (Berlin, 2009) participants, and two anonymous referees for useful comments. Financial support of GAČR Grant No. 402/09/1595 is gratefully acknowledged. The usual disclaimer applies.

${ }^{1}$ The vast majority of studies cover the USA (e.g. Boatsman and Gupta, 1996; Navarro, 1988) or the UK (e.g. Campbell et al., 2002; Brammer and Pavelin, 2005).
} 
(1996) employed panel data and firm-specific variables with a similar dataset and showed that giving serves as a quasi-fringe benefit to employees through its impact on the community or environment, and that giving is lower due to free riding, as firms in communities with a high number of firms give less. Thus, they conclude that giving is motivated by the maximization of managerial utility under a binding budget constraint. ${ }^{2}$ In our paper we follow part of the existing literature that is linked to the legal framework and tax legislation, using various tax treatments as major factors explaining corporate giving.

From the tax treatment point of view we can identify three major different ways in which corporations support nonprofit organizations: sponsoring, giving, and tax assignation. Sponsoring is often compared to advertising and is a cost that decreases taxable income without further restrictions. The extent of sponsoring is therefore affected by the corporate tax rate. Giving can be in financial or "in-kind" form. It is a cost that is tax-deductible up to a limit. Therefore, the extent of giving depends on both the tax rate as well as the tax-deductible limit. Tax assignation, which exists only in a few countries, allows corporations (as well as individuals) to assign a fraction of their taxes to particular purposes, namely, to publicly listed beneficial organizations, which are most often non-profit organizations.

With respect to the above types of corporate philanthropy the problem with the existing empirical studies is that they do not always accurately distinguish between giving and sponsoring and therefore the tax legislation effect is likely to be incorrectly measured. Furthermore, these studies typically cover only one country. In this paper we use data on corporate philanthropy in the Czech and Slovak Republics. We will analyze the effect of tax policies on corporate behavior. Moreover, we use data on two countries that for more than 70 years shared the same history and have close cultural roots. Until 1993 both countries were part of the former Czechoslovakia, a federation of these two countries. Following their separation in 1993 these countries, which are broadly similar in terms of culture, language, values, ethics, norms, etc., adopted different legislation and tax policies. These settings are close to a natural experiment and allow us to properly identify the effects of the tax rate and tax policies on corporate philanthropy. Since we compare two countries with a long common history but different recent evolutions, the observed (recent) differences in corporate-giving tax legislation are expected to reveal differences in the philanthropic behavior of firms. Moreover, in our analysis we are also able to distinguish between sponsoring and giving, two philanthropic channels that have very different tax implications. In other words, we are able to properly identify and test for the importance of tax policies. ${ }^{3}$ Last but not least, during the period studied one country (Slovakia) changed its policy regarding tax deductibility and allowed tax assignation, so we can also estimate the effect of this policy change. The paper thus provides important insights regarding the relevance of tax policies for corporate philanthropy decision-making.

\footnotetext{
${ }^{2}$ A possible cause of the opposite results in the two studies is the data and measures used. Navarro (1988) works with cross-sectional data, thus it is possible that there are unobservable firm characteristics that may bias the results. Another bias may be caused by measurement error in the tax rate: Navarro (1988) uses the average tax rate instead of the marginal tax rate, which is used in theoretical models and is also used in Boatsman and Gupta (1996).

${ }^{3}$ This leads to an empirical evaluation of the Galaskiewicz and Colman (2006) hypothesis that the motivation of companies varies across the different giving tools they employ.
} 
The rest of the paper is organized in the following manner. In Section 2 we describe the current literature on corporate philanthropy in the two countries. In Section 3 we describe the theoretical framework for studying corporate philanthropy and formulate testable hypotheses. The data are introduced in Section 4. We present our results in Section 5, where we show that the Slovak Republic lags behind the Czech Republic, particularly in corporate giving. Further, we fail to find support for the claim that foreign firms are more generous than domestic ones (e.g., Bussard et al., 2005; BLF CR, 2004). The results about the importance of tax legislation are mixed. Section 6 offers our conclusions.

\section{Corporate Philanthropy in the Czech and Slovak Republics}

This study fills a gap in the existing literature as it is one of the few quantitative analyses of corporate philanthropy in European emerging markets. The few studies dealing with transformation economies (e.g., Russia: King and Tchepournyhk, 2004; Ukraine: Ilko, 2004; NDS, 2005; Velšic, 2004) are all qualitative. The two exceptions are the study by Marček and Dluhá (2002) analyzing the donations of a sample of 107 Slovak firms, and a study conducted in the Czech Republic by Donors Forum (DF, 2004). The latter is an analysis of a survey of corporate giving in the Czech Republic. In the current study, we work with the data from this survey extended with additional data collected for the Czech Republic and Slovakia. During the period 2001-2005, which is the span of our data, both the Czech and Slovak Republics were considered established market economies, as attested by their accession to the EU in 2004 (CERGE-EI, 2004; IVO, 2002). The label is optimistic with respect to corporate philanthropy, though. Corporate philanthropy in transformation economies has a short history, as it started to develop only after the demise of the command economic system. For that reason the business environment still exhibits specific features that may affect the philanthropic behavior of companies and result in different behavior than that observed in developed market economies.

First, the market environment itself is not developed in European emerging markets to the extent observed in developed economies and its evolution has typically been very turbulent. In particular the early years of transition were marked by significant uncertainty, low transparency, and high levels of corruption. Problems with transparency and corruption also remain present due to inefficient and complicated legal systems (Estrin et al., 2009; Lízal and Kočenda, 2002; CERGE-EI, 2004). ${ }^{4}$ Uncertainty in Slovakia was higher until 1998 due to political instability, marked by a severe lack of transparency, corruption, and politically motivated decisions. Many of these problems remained after the change of government in 1998, although their intensity decreased significantly (IVO, 2002). A number of important changes improving the Slovak market environment occurred in 2003-2004, namely, reforms of tax legislation, health care, and the pension system.

Countries in transition continue to lag behind their more developed counterparts also in their economic performance, an important determinant of corporate

\footnotetext{
${ }^{4}$ The corruption perception index in both countries is increasing very slowly. That means that the corruption environment is improving slowly as well. In 2008, it was 5.2 for the Czech Republic and 5.0 for the Slovak Republic on a 10 point scale (10 being the least corrupt or corruption-free). This translates into $45^{\text {th }}$ and $52^{\text {nd }}$ place, respectively, among 180 countries, according to Transparency International.
} 
charity. ${ }^{5}$ Lower levels of giving in post-communist countries are, indeed, often explained by the unfavorable economic conditions (Kivilo, 2005; Ilko, 2004; King and Tchepournyhk, 2004; Marček and Dluhá, 2002). Fidrmuc and Gerxhani (2005) show that unfavorable economic conditions during transformation account also for the low stock of social capital in post-communist countries, measured by civic participation and access to social networks. Nevertheless, the OECD states that both the Czech and Slovak Republics have experienced significant economic growth in the periods under consideration, which might be a reason for parallel growth in corporate philanthropy.

A lack of a tradition of philanthropy is another feature of transition countries that is expected to strongly negatively influence corporate charitable behavior. The development and popularization of corporate social responsibility has been supported by the International Business Leaders Forum (BLF), a nonprofit organization with national branches in both countries (since 1992 in the Czech Republic and since 2004 in Slovakia). Nevertheless, the number of companies understanding and implementing the concept of philanthropy remains low in both countries (Czech Republic: BLF CR, 2004; Slovakia: WB, 2004). One of the possible explanations of this low engagement is, according to the Business Leaders Forum for the Slovak Republic (2005), the ignorance of the public causing insufficient pressure on companies to get involved.

Both countries joined the European Union in 2004, an important step that concluded the accession period that lasted in both countries for more than five years. Therefore, we do not place special emphasis on the point of accession itself and observe the EU's indirect influence as the motivation for economic growth and increased activity of local and international initiatives supporting philanthropy (BLF, Donors Forum).

Yet another important feature affecting the level of corporate philanthropy is the legal framework. The laws in the Czech and Slovak Republics, including those relevant to corporate philanthropy, were very similar (e.g., Lízal and Kočenda, 2002) until 2004, when several major changes were made in Slovakia. In the short review below, we focus on three different tools that corporations use to support nonprofit organizations: sponsoring, giving, and in Slovakia also tax assignation.

The three forms of corporate support can be distinguished based on their tax treatment. Sponsoring, governed by a sponsoring contract, is often compared to advertising. Expenditures on sponsoring enter the books as costs, decreasing taxable income without further restrictions. The corporate tax rate is therefore the only legal factor that influences expenditures on sponsoring. Due to the income effect, increasing the tax rate increases sponsoring, because its price is lower. However, the income from sponsoring is business income for the receiving organization and it has to be taxed.

Giving, governed by a donation contract, includes financial donations or "in-kind" donations of products and services. Expenditures on giving typically represent after-tax expenditures that are tax-deductible up to a limit. Therefore, the extent of giving depends not only on the corporate income tax rate, as in sponsoring, but also on the tax-deductible limit. The limits vary across countries, and their evolution in

\footnotetext{
${ }^{5}$ Corporate giving remains a relatively stable fraction of before-tax profits in the USA (Clotfelter, 1985; Galaskiewicz and Colman, 2006).
} 
Table 1 Tax Legislation

\begin{tabular}{|c|c|}
\hline Czech Republic & Slovak Republic \\
\hline \multicolumn{2}{|c|}{ Limit on tax-deductibility } \\
\hline \multicolumn{2}{|l|}{$2 \%$ of tax-base } \\
\hline \multicolumn{2}{|l|}{$5 \%$ (if natural disaster causes) } \\
\hline $10 \%$ for $2002-2003$ (floods) & Since 2004 - no deductibility \\
\hline \multicolumn{2}{|c|}{ Corporate tax rate } \\
\hline Until 2004 & $2000-2001$ \\
\hline 2004 & 2002-2003 \\
\hline 2005 & 2004 \\
\hline 2006 & \\
\hline 2008 & \\
\hline & since 2003 \\
\hline
\end{tabular}

Sources: CR: The Act on Income Taxes No. 586/1992 Coll. in the wording of its future amendments; SR: The Act on Income Taxes No. 595/2003 Coll.

the Czech Republic and Slovak Republic is summarized in Table 1. The legislation in the Czech Republic has become complex, with many additional exemptions and changes in the limit having been introduced in the last four years. ${ }^{6}$ The limit in Slovakia was stable at $2 \%$ of taxable income until 2004, when new legislation abolished the deductibility of donations. ${ }^{7}$

Tax assignation exists in Slovakia but not in the Czech Republic. It allows corporations (and physical persons) to assign a fraction of their taxes to particular purposes, namely, to publicly listed beneficial organizations, most often nonprofit organizations. The assigned funds belong to the state. The government delegates the decision about how to distribute the assigned funds (collected taxes) to taxpayers if they choose to do so. The tax assignation scheme has applied to corporations since 2003 with a $1 \%$ cap. In 2004 the fraction that may be assigned was increased to $2 \%$ for both corporations and physical persons. While tax assignation for physical persons exists in other transition countries, ${ }^{8}$ tax assignation for corporations is unique to Slovakia. Tax assignation represents an additional source of funds for nonprofits ${ }^{9}$ and we include it, to certain extent, in this study even though it is not philanthropy in its true sense. Corporations that assign do not donate their own resources, they only distribute a fraction of state funds. Nevertheless, firms usually consider assignation a form of philanthropy, possibly because assignation requires the firm to make a decision and show some interest in the organization it supports. ${ }^{10}$

\footnotetext{
${ }^{6}$ The Act on Income Taxes No. 586/1992 Coll., as amended.

${ }^{7}$ The Act on Income Taxes No. 595/2003 Coll. In both countries donations had to be deducted in the year they were given (unlike in the USA, where there is the option to carry forward donations above the limit). State-owned companies did not have the right to deduct any gifts. Still, we argue that due to the heavy presence of the state in many privatized firms (Hanousek and Kočenda, 2008) these firms in fact possibly provided non-marginal donations.

${ }^{8}$ For example, Hungary, where it was first introduced, or Poland (www.onepercent.hu).

${ }^{9}$ Tax assignation is, indeed, a significant additional source of income. In 2004 corporations assigned SKK 570 million, 92\% of the total amount they could have assigned. In addition, SKK 276 million was assigned by physical persons. The amount has been increasing steadily ever since. The amount assigned by corporations was nearly SKK 900 million in 2007, with an additional 380 million assigned by individuals (www.rozhodni.sk).
} 


\section{Theoretical Foundations of Corporate Giving}

The theoretical framework for corporate giving was initially developed by Clotfelter (1985) and was later extended by Navarro (1988). Boatsman and Gupta (1996) employed it to illustrate the impact of a budget constraint imposed on the manager, and Jankech (2002) used it to account for deductions above the tax deductible limit. The basic model and its extensions predict that the tax rate affects the level of donations if giving is motivated by the maximization of managerial utility, and does not affect the level of donations if the company maximizes profit. If there is a budget constraint imposed on the managers, then the tax rate will have a negative impact when the constraint binds and it will have a positive impact on donations if the constraint does not bind. Jankech (2002) proves that these predictions remain valid also for the case when there is a binding tax deductible limit on donations.

However, the predictions of the model and its extensions hinge on the assumption that the model is one period only, which does not allow accounting for the long-run payoffs of giving: donations given today bring direct payoffs similar to advertising but also build goodwill that pays off in the future. The model of Clotfelter (1985) has been extended by Boatsman and Gupta (1996) into a two-period model that captures the above long-run effects. However, this two-period model does not allow for the maximization of utility; it illustrates only the profit-maximizing case. In this setting the predictions formulated above and used in all previous empirical studies do not hold. If a firm maximizes profit over several periods, then the tax rate affects the optimal level of giving because it is optimal to shift giving to periods when it is cheaper (i.e., when the tax rate is higher). The extent of these shifts depends on the discount factor and the rate of depreciation of accumulated capital.

If there is no depreciation it is optimal to give most when it is cheapest and "live" from the payoffs later on. The rate of goodwill depreciation depends on the corporate environment. Corporations may decrease it by establishing a foundation which collects donations in good years and pays them out smoothly over time, ensuring payoffs in later periods for a good price.

In this paper we build on the two-period model of Clotfelter (1985) to allow for long-run payoffs of giving in the utility-maximizing case. The theoretical base for our empirical analysis will be a model in which we merge the two main philanthropy motivations by assuming that a manager's utility is a convex combination of giving and after-tax profit. In that sense, the manager chooses donations and pricing to maximize his utility function in the following form:

$$
\begin{aligned}
& U\left[p_{1}, p_{2}, g_{1}, g_{2}\right]=\alpha\left(1-t_{1}\right)\left(p_{1} Q_{1}\left[p_{1}, g_{1}\right]-g_{1}\right)+(1-\alpha) g_{1}+ \\
& +\delta\left(\alpha\left(1-t_{2}\right)\left(p_{2} Q_{2}\left[p_{2}, \beta g_{1}+g_{2}\right]-g_{2}\right)+(1-\alpha) g_{2}\right) \\
& \pi=(1-t) p Q[p, g]-g
\end{aligned}
$$

Here, $\pi$ represents the after-tax profit of the company, $Q[p, g]$ is the demand function, $p$ is the price of the good produced, $g$ is giving in the given period, $\alpha$ is

\footnotetext{
${ }^{10}$ Assignation can have some of the positive effects of philanthropy for firms and therefore should be considered quasi-philanthropy. According to a survey performed in $2005,84 \%$ of companies considered assignation a form of philanthropy (NDS, 2005).
} 
the preference of the manager for the maximization of corporate profit, $\delta$ is the depreciation, and $\beta$ is the "depreciation" of the goodwill of the donation from the first period.

Profit and utility maximization remain limiting cases. The predictions of this extended model further support Clotfelter's (1985) prediction that the tax rate matters for the level of donations especially if the company gives to maximize its profits. In summary, the various extensions of the basic theoretical model of corporate giving give mixed predictions regarding the interpretation of the tax rate as an indicator of the motivation for giving. We have therefore decided to base our empirical analysis on this standard model but refrain from interpretation of the tax rate as the indicator of the motivation for giving.

The empirical model is based on the theoretical model explained above and extended to consider organizational characteristics. We examine two specifications, one for the amount spent on sponsoring and one for giving (denoted in general philanthropy, Phil):

$$
\begin{aligned}
\text { Phil }_{i . t}= & \beta_{0}+\beta_{1} \text { Size }_{i, t}+\beta_{2} \text { IndD }_{i}+\beta_{3} \text { LopD }_{i}+\beta_{4} \text { Capital }_{i}+\beta_{5} \text { OwnD }_{i}+ \\
& +\beta_{6} \text { FD }_{i}+\beta_{7} \text { Year }+\beta_{8} \operatorname{Tax}_{i}+\beta_{9} \text { CRII }_{i}+\mu
\end{aligned}
$$

The explanatory variables in specification (2) are coded in the following manner: Size captures the size of the company, which is used to normalize the levels of giving (big companies give more in absolute terms). Size is measured by two variables: Sales, the volume of sales, and NoE, the number of employees. Dummy variables IndD indicate different industries: manufacturing, retail, and services. They capture possible differences in the reliance on philanthropy across different industries. Industries closer to their customers are expected to give more. We use services as the benchmark group. Categorical variable LopD indicates the level of operation: international, national, or regional. This variable captures the potential power and expectations of a company's stakeholders. Dummy variable Capital indicates firms located in the capitals Bratislava or Prague. Dummy variable OwnD indicates different ownership structures: foreign, mixed, or domestic. The variables are expected to capture differences in the philanthropic culture and the behavior of domestic and foreign owners, as the corporate performance of these firms differs as well (Hanousek, Kočenda, and Svejnar, 2007; Bena and Hanousek, 2008). Dummy variable FD distinguishes firms with a foundation or a foundation fund. It captures the possible strategic philanthropic behavior of a firm, signaling higher engagement in philanthropy. Categorical variable Year captures the possible time trend in giving. Dummy variable TaxD represents four dummy variables indicating different corporate tax rates. There were three different tax rates in Slovakia and three in the Czech Republic. The tax dummies are denoted Tax1 SR (2001), Tax2 SR (2002-2003), Tax3 SR (2004), Tax1 CR (2001-2003), Tax2 CR (2004), and Tax3 CR (2005). Two for each country are included in the regressions; the third one is set as a benchmark. Dummy variable $C R$ II denotes the additional, second sample for the Czech Republic. Technically, we use the logarithmic transformation of the amount variables (the dependent and applicable explanatory variables) to directly obtain estimates of elasticities. Finally, in the model we do not include profitability as an explanatory variable because of its potential endogeneity. If corporations use philanthropy to maximize profits, then 
the amount of giving is determined by profitability but it is also expected to affect profits. In order to account for the endogeneity of profitability we would have to use instrumental variables. Unfortunately, our data set does not contain a suitable instrumental variable. Therefore, we opt for omitting profitability in our specification, since omitted variable bias presents a smaller problem than endogeneity.

The panel format of the data that we collected and describe in detail in Section 4 allows accounting for unobservable firm-specific effects using either a random or fixed effects specification, REM or FEM (Wooldridge, 2002). We test for the appropriate specification comparing the pooled OLS regression, REM, and FEM. If FEM proves to be the correct specification, we estimate an additional random effects model on the residuals from FEM to evaluate the effects of the observable firm characteristics of interest (Wooldridge, 2003). We employ Heckman's two step procedure to correct the potential self-selection of firms (Green, 1993). For comparison, we estimate the model also using the interval regression, but this is possible only in the REM specification using maximum likelihood. ${ }^{11}$ To account for simultaneity in the giving and sponsoring decisions we also estimate a system of seemingly unrelated equations.

\subsection{Hypotheses}

The hypotheses are developed based on the predictions of the theoretical model adjusted to the specifics of transition economies. The lower appreciation of corporate charitable behavior by consumers is captured by the relatively small impact of giving on demand, $Q_{G}>0$, and similarly small utility "payoffs" to managers, i.e., utility gained from other perks is higher. On the other hand, the uncertain, non-transparent environment of transition increases the occurrence of principal-agent problems, giving managers more opportunities to divert funds. The final effect of these factors remains to be tested empirically. In the following account we motivate our hypotheses along with their formulations.

We assume that firms optimize their behavior over several periods and therefore have incentives to inter-temporarily shift their donations to years when it is cheaper, i.e., when the tax rate is higher. This behavior is enforced by the motivation to optimize tax dues: firms, particularly in transition, often seek to minimize their tax obligations by avoiding taxes (Hanousek and Palda, 2003 and 2004). ${ }^{12}$ The tax rates in both countries declined in the studied period and the changes were announced in advance, hence, firms were able to shift their donations to earlier periods. The changes in the Czech Republic were smaller than those in the Slovak Republic, thus we expect a lower impact. The most significant changes occurred in Slovakia in 2004, thus we expect this change to have the most significant effect.

\section{Hypothesis 1: The tax policy affects charitable behavior, i.e., the tax rate plays a significant role in the giving decision.}

Following Galaskiewicz and Coleman (2006), who suggest that different giving tools are motivated differently, we distinguish two philanthropic tools: sponsor-

\footnotetext{
${ }^{11}$ There are not sufficient statistics to estimate conditional FEM; the estimates in unconditional fixed effects are biased (Stata manual).

${ }^{12}$ We claim that firms that engage in philanthropy tend to avoid rather than evade taxes, as they are more "visible" because of their philanthropic activities. If they preferred to evade taxes, we claim that they would not invest in charity and attract unwanted attention. Thus, we do not expect evasion to make estimation problematic.
} 
ing and giving. Each is subject to a different tax treatment. Sponsoring has a more favorable tax treatment than giving, and we therefore expect that the tax rate will have a stronger impact on sponsoring. The tax treatment for giving is more favorable in the Czech Republic than in Slovakia, so we expect that the preference for sponsoring will be stronger in Slovakia.

\section{Hypothesis 2: The tax rate has a stronger impact on sponsoring than on giving.}

The size of the company is a typical factor influencing expenditures on philanthropy. This is natural, as large companies have more funds available, thus they spend more in absolute amounts also on charity. ${ }^{13}$

\section{Hypothesis 3: Bigger companies spend more on philanthropy.}

The ownership of the company is another factor that influences philanthropy. Namely, it is often claimed that foreign owners transplant their home corporate culture, where philanthropic traditions are more established (Bussard et al., 2005). Companies with foreign owners are therefore expected to take the lead in philanthropic behavior in transition economies (e.g., BLF CR, 2004; Bussard et al., 2005), possibly due to their better performance (Hanousek, Kočenda, and Svejnar, 2007). An additional factor increasing the giving of foreign companies may be a higher need to build relationships and goodwill in the country.

\section{Hypothesis 4: Foreign-owned companies spend more on philanthropy.}

Corporate giving might also be determined by the industry the company operates in (Clotfelter, 1985; Abzug and Webb, 1997). Engagement in philanthropy is more important for firms in services because they are closer to their customers and need to be visible in the community, and for retail firms because they deal with large groups of consumers. These pressures are the smallest in manufacturing. An additional argument is the relatively lower mobility of firms in services or retail, which further increases the importance of community engagement.

\section{Hypothesis 5: Firms in retail and services spend more on philanthropy than firms in manufacturing.}

Firms operating at the local, national, and international levels face different conditions and meet different stakeholder groups. Firms operating at the international level meet stronger stakeholder groups and operate in an environment with higher expectations regarding corporate behavior (Abzug and Webb, 1997). These factors increase the pressure to engage in philanthropy. On the other hand, firms operating at the regional level are closer to their stakeholders and the needs of the local community. Which of these forces is stronger is an empirical question.

\section{Hypothesis 6: The geographic level of operation affects the philanthropic behavior of companies.}

The last factor we want to discuss is location. We assume that the biggest difference in philanthropic behavior exists between firms located in the capital city and those located in other regions. However, what direction this difference goes in is not

\footnotetext{
${ }^{13}$ Large companies have more funds available, but smaller firms often perform better than large ones (Hanousek, Kočenda, and Svejnar, 2009).
} 
clear. Philanthropic engagement in the capital could be expected to be lower because firms in areas with many other companies tend to free ride on the giving of others (Navarro, 1988) and it is more difficult to build relationships and cooperation due to anonymity. However, engagement could be expected to be higher in the capital because companies tend to have more resources and there is a higher density of nonprofit organizations, increasing the pressure to give (Navarro, 1988). Which of these forces is stronger is an empirical question.

\section{Hypothesis 7: The philanthropic behavior of firms located in capital cities differs from that of firms in other regions.}

\section{Data}

Despite considerable difficulties with data availability we assembled a unique dataset on corporate philanthropy. ${ }^{14}$ Data for the Czech Republic were collected by market survey company Median (Median SR in SR) in two surveys using face-to-face interviews: the first sample was collected for the Czech Donors Forum in 2004, covering 577 firms over three years (2001-2003), with over-sampling of large and medium-sized firms. ${ }^{15}$ The second sample was collected in 2006, covering 162 firms over five years (2001-2005), focusing entirely on large and medium-sized firms. The Slovak sample was collected in 2005, covering 152 firms over four years (2001-2004). Here, too, large and medium-sized firms are over-sampled. Details about the samples are summarized in Table 2. Unfortunately, a new wave of the survey scheduled for 2008-2009 was cancelled and therefore we have to work solely with the datasets mentioned above.

The focus of our surveys was on quantitative information about corporate philanthropy allowing us to test our hypotheses. We collected specific information on the amounts spent on sponsoring and giving, the number of entities supported, the areas supported, and the target groups, and information about the companies (number of employees, industry, geographical area, legal form, level of operation, sales, and income before taxes). Because we work with survey data we have to address the problem of sample selection: small firms and firms with no or low contributions are less likely to participate in corporate philanthropy (Navarro, 1988; Helland and Smith, 2003). This problem is mitigated to some extent by the fact that we have information on sponsoring and giving, i.e., we have information for firms that did not give but sponsored and vice versa. The second problem is with the quality of data on philanthropic expenditures: corporations are reluctant to publicize any specific information regarding their philanthropic spending (Kivilo, 2004; Múčka, 2005; Marček and Dluhá, 2002) and accounting regulation of giving is complicated and unclear, particularly for material gifts and services. We addressed this problem by allowing the respondents to report the spending information in intervals. Unfortunately, the first interval (for giving and sponsoring) in the original Czech survey

\footnotetext{
${ }^{14}$ Only one of the existing studies on the Slovak Republic includes information on the amounts spent (for 2001, Marček and Dluhá, 2002). The only study on the Czech Republic is the one by Donors Forum (DF, 2004); we work with this data.

${ }^{15}$ A representative sample would consist $98 \%$ of firms having less than 50 employees, providing insufficient information on big firms, which are the most important givers. In addition, the sample included a group of big firms specified by Donors Forum, which may bias the results slightly, even though the sample was made representative afterwards.
} 
Table 2 Structure of the Samples

\begin{tabular}{|c|c|c|c|c|c|c|}
\hline & CRI & $\%$ & CR II & $\%$ & SR & $\%$ \\
\hline \multicolumn{7}{|l|}{ Number of employees } \\
\hline Less than 50 & 310 & 54 & - & - & 67 & 44 \\
\hline $50-250$ & 194 & 34 & 108 & 67 & 56 & 37 \\
\hline $250-1000$ & 48 & 8 & 41 & 25 & 25 & 16 \\
\hline 1000 and more & 25 & 4 & 13 & 8 & 4 & 3 \\
\hline \multicolumn{7}{|l|}{ Ownership } \\
\hline Foreign & 38 & 7 & 21 & 13 & 21 & 14 \\
\hline More foreign & 31 & 5 & 10 & 6 & 9 & 6 \\
\hline More domestic & 54 & 9 & 41 & 25 & 26 & 18 \\
\hline Domestic & 454 & 79 & 90 & 56 & 94 & 62 \\
\hline \multicolumn{7}{|l|}{ Level of operation } \\
\hline International & 90 & 16 & 50 & 31 & 48 & 33 \\
\hline National & 148 & 25 & 65 & 40 & 57 & 38 \\
\hline Regional & 339 & 59 & 47 & 29 & 43 & 29 \\
\hline \multicolumn{7}{|l|}{ Industry } \\
\hline Manufacturing & 248 & 43 & 110 & 68 & 90 & 60 \\
\hline Retail & 135 & 23 & 7 & 4 & 27 & 18 \\
\hline Services & 194 & 34 & 45 & 28 & 33 & 22 \\
\hline Total & 577 & 100 & 162 & 100 & 152 & 100 \\
\hline
\end{tabular}

Sources: CR I: Survey by Donor's Forum (DF, 2004), CR II: Survey on request of the authors conducted by Median CR in 2006, SR: Survey on request of the authors conducted by Median SR in 2005. All, three surveys used the same questionnaire to allow for comparison. Authors' computation.

Table 3 Comparison CR/SR, Basic Indicators

\begin{tabular}{l|ccc|ccc|c}
\hline & \multicolumn{3}{|c|}{ Sponsoring } & \multicolumn{3}{c|}{ Giving } & $\begin{array}{c}\text { Assigna- } \\
\text { tion }\end{array}$ \\
\cline { 2 - 7 } & $\mathrm{CR}$ & $\mathrm{SR}$ & Wald test & $\mathrm{CR}$ & $\mathrm{SR}$ & Wald test & SR \\
\hline Participation & 0.56 & 0.60 & & 0.61 & 0.42 & $* * *$ & 0.51 \\
& $(0.01)$ & $(0.03)$ & & $(0.01)$ & $(0.03)$ & & $(0.04)$ \\
Amount & 471.75 & 133.41 & $* * *$ & 375.85 & 58.61 & $* * *$ & \\
Amount (CI) & $(63)$ & $(33.07)$ & & $(64.76)$ & $(16.97)$ & & \\
& 317.13 & 167.43 & $* * *$ & 246.15 & 101.75 & $* * *$ & \\
Amount/profit & $(-24.4)$ & $(32.37)$ & & -18.36 & $(16.67)$ & & \\
Amount/profit & 0.33 & 0.11 & $* * *$ & 0.44 & 0.05 & $* * *$ & \\
(Cl) & $(0.04)$ & $(0.02)$ & & $(0.06)$ & $(0.01)$ & & \\
\hline
\end{tabular}

Notes:Standard errors are in parentheses. ${ }^{* * *}$ denotes significant difference between the means in CR and SR at $1 \%$.

Amounts are in thousands CZK, adjusted for inflation with base year 2001.Common intervals $(\mathrm{Cl})$ allow a better comparison of the samples. They group data from the narrow intervals in the SR and CR II samples to form the large first interval in the original CR sample, and vice versa for the high categories.

was very broad, up to CZK 200,000. As a result nearly $79 \%$ of the reported giving (company/year) fell into this interval. In the subsequent surveys we split this interval into four subcategories, and to maintain the number of intervals we merged the top three intervals. ${ }^{16}$ Lastly, the respondents reported the information retrospectively, which also decreases the quality of the data. However, this problem was mitigated by arranging the interviews in advance and giving the respondents time to prepare.

${ }^{16}$ Throughout the study we work with different intervals for different samples. We provide results with common intervals when different from the standard. 
Table 3 summarizes the aggregate information for both countries: the fraction of firms that participate in sponsoring/giving (Participation), the average amount spent on sponsoring/giving (Amount), the average amount reported in common intervals (CI), sponsoring/giving as a fraction of profits before taxes (average amount divided by profit before tax, Amount/profit), and sponsoring/giving as a fraction of profits before taxes in CI. The data in Table 3 and subsequent estimations are weighted to be representative of the population of firms in the country. We used the Wald test to test for the equality of means between the two countries; the results are provided in the last column.

We observe that the two countries are very different: sponsoring participation and expenditures as a fraction of profit in CI are the only categories where we fail to reject the null hypothesis of equality between the countries. The differences between the data reported using the original and common intervals illustrate the biases caused by the size of the original first interval (Slovak Republic) and the merging of the last intervals (Czech Republic). Nevertheless, even in common intervals the differences between the countries remain significant and Slovakia lags behind the Czech Republic. One reason may be a difference in the profitability of companies: profits in Slovakia are significantly below those in the Czech Republic (the average profit in the Czech Republic was CZK 227,431,000, while that in the Slovak Republic was CZK 14,040,000). ${ }^{17}$ Assignation participation (Slovak Republic) is significantly above giving participation (at the $10 \%$ level). A comparison of assignation participation to that obtained in the unweighted sample illustrates that small firms assign less often. ${ }^{18}$ This result is in line with the fact that the probability of low (zero) profit among small firms is higher because these firms pay no or low taxes, so they have nothing to assign. The result is similar for giving participation. ${ }^{19}$

\section{Results}

\subsection{Participation}

In this section we report the results on sponsoring and giving participation and, for the Slovak Republic, also participation in assignation. The sponsoring and giving specifications also provide an estimate of Heckman's selection parameter, $\lambda$. The model is estimated separately for the Czech and the Slovak Republics because the Chow test of the equality of coefficients rejected the hypothesis of equality of the two samples. The test failed to reject the hypothesis in the comparison of the two Czech samples, so we merge the two. To account for the difference in levels ${ }^{20}$ we use a dummy variable (CR II) denoting the second sample. We estimated a linear probability model, probit, and a system of seemingly unrelated equations, but we report only

\footnotetext{
${ }^{17}$ The difference is driven by the less than $1 \%$ of firms with very high profits, which are missing in the Slovak sample. The result is even stronger when we take into account that the fraction of firms that reported profits was higher in the Slovak Republic; more than $70 \%$ of firms in Slovakia reported a profit, while the fraction in the Czech Republic is only around $50 \%$.

${ }^{18}$ This comparison is available on request.

${ }^{19}$ We have no data on the amounts assigned. This question was omitted from the survey as we did not expect any company to assign less than the $2 \%$ allowed by law. However, we did ask the companies whether they used assignations to the full extent, and only $9 \%$ responded that they assigned less than $2 \%$.

${ }^{20}$ The original sample included several large donors.
} 
Table 4 Participation, Random Effects Probit

\begin{tabular}{|c|c|c|c|c|c|}
\hline & \multicolumn{2}{|c|}{ Sponsoring } & \multicolumn{2}{|c|}{ Giving } & \multirow{2}{*}{$\begin{array}{c}\begin{array}{c}\text { Assigna- } \\
\text { tions }\end{array} \\
\mathrm{SR}\end{array}$} \\
\hline & CR & SR & CR & SR & \\
\hline Number of employees & $\begin{array}{c}0.61^{*} \\
(0.33)\end{array}$ & $\begin{array}{l}-0.56 \\
(0.49)\end{array}$ & $\begin{array}{l}0.91^{* * *} \\
(0.32)\end{array}$ & $\begin{array}{c}1.09^{* *} \\
(0.52)\end{array}$ & $\begin{array}{l}-0.97^{*} \\
(0.51)\end{array}$ \\
\hline Sales log & $\begin{array}{l}0.32^{* * *} \\
(0.07)\end{array}$ & $\begin{array}{c}0.4^{\star \star} \\
(0.18)\end{array}$ & $\begin{array}{l}0.35^{\star * \star} \\
(0.07)\end{array}$ & $\begin{array}{c}0.23 \\
(0.19)\end{array}$ & $\begin{array}{l}0.91^{* * *} \\
(0.22)\end{array}$ \\
\hline Manufacturing & $\begin{array}{l}-0.69 * * \\
(0.34)\end{array}$ & $\begin{array}{c}1.08 \\
(0.73)\end{array}$ & $\begin{array}{l}-0.06 \\
(0.33)\end{array}$ & $\begin{array}{l}0.26 \\
(0.7)\end{array}$ & $\begin{array}{c}0.96 \\
(0.71)\end{array}$ \\
\hline Retail & $\begin{array}{l}-0.58^{*} \\
(0.32)\end{array}$ & $\begin{array}{c}1.6^{\star *} \\
(0.75)\end{array}$ & $\begin{array}{c}0.42 \\
(0.37)\end{array}$ & $\begin{array}{c}1.74^{* *} \\
(0.72)\end{array}$ & $\begin{array}{c}0.68 \\
(0.74)\end{array}$ \\
\hline Level of operation & $\begin{array}{l}-0.13 \\
(0.24)\end{array}$ & $\begin{array}{l}-1.93^{* * *} \\
(0.39)\end{array}$ & $\begin{array}{l}0.84^{* * *} \\
(0.23)\end{array}$ & $\begin{array}{l}-1.01^{* *} \\
(0.38)\end{array}$ & $\begin{array}{l}-1.52^{* * *} \\
(0.41)\end{array}$ \\
\hline Capital & $\begin{array}{l}-1.08^{* *} \\
(0.44)\end{array}$ & $\begin{array}{l}-0.04 \\
(0.92)\end{array}$ & $\begin{array}{l}-1.36^{* * *} \\
(0.45)\end{array}$ & $\begin{array}{l}-2.23^{\star \star *} \\
(0.85)\end{array}$ & $\begin{array}{l}2.33^{* *} \\
(0.99)\end{array}$ \\
\hline Foreign own & $\begin{array}{c}1.28 \\
(0.89)\end{array}$ & $\begin{array}{l}-5.4^{\star * *} \\
(1.04)\end{array}$ & $\begin{array}{l}1.28^{*} \\
(0.75)\end{array}$ & $\begin{array}{l}-0.2 \\
(0.96)\end{array}$ & $\begin{array}{l}-1.71^{*} \\
(1)\end{array}$ \\
\hline Mixed own & $\begin{array}{c}0.54 \\
(0.45)\end{array}$ & $\begin{array}{l}-0.27 \\
(0.72)\end{array}$ & $\begin{array}{l}-0.51 \\
(0.44)\end{array}$ & $\begin{array}{c}1.09 \\
(0.67)\end{array}$ & $\begin{array}{l}-1.16 \\
(0.75)\end{array}$ \\
\hline CR II & $\begin{array}{l}-0.74 \\
(0.6)\end{array}$ & & $\begin{array}{c}0.06 \\
(0.59)\end{array}$ & & \\
\hline Year & $\begin{array}{c}0.3^{* * *} \\
(0.08)\end{array}$ & $\begin{array}{c}0.02 \\
(0.39)\end{array}$ & $\begin{array}{l}0.32^{* * *} \\
(0.07)\end{array}$ & $\begin{array}{l}0.1 \\
(0.34)\end{array}$ & $\begin{array}{c}0.29 \\
(0.3)\end{array}$ \\
\hline Tax1 CR & $\begin{array}{c}0.19 \\
(0.57)\end{array}$ & & $\begin{array}{l}-0.64 \\
(0.6)\end{array}$ & & \\
\hline Tax2 CR & $\begin{array}{c}0.28 \\
(0.63)\end{array}$ & & $\begin{array}{c}0.05 \\
(0.65)\end{array}$ & & \\
\hline Tax1 SR & & $\begin{array}{l}-0.05 \\
(0.68)\end{array}$ & & $\begin{array}{l}-0.24 \\
(0.6)\end{array}$ & \\
\hline Tax3 SR & & & & $\begin{array}{c}0.09 \\
(0.58)\end{array}$ & \\
\hline Constant & $\begin{array}{l}-3.61^{\star * *} \\
(1.12)\end{array}$ & $\begin{array}{c}1.25 \\
(2.37) \\
\end{array}$ & $\begin{array}{l}-6.21^{* * *} \\
(1.19) \\
\end{array}$ & $\begin{array}{l}-3.13 \\
(2.44) \\
\end{array}$ & $\begin{array}{l}-6.36 \\
(2.75) \\
\end{array}$ \\
\hline No. of obs. & 1665 & 504 & 1665 & 504 & 254 \\
\hline Log-likelihood & -608.92 & -107.12 & -611.94 & -139.33 & 94.57 \\
\hline
\end{tabular}

Notes: Standard errors are in parentheses.

${ }^{* * *}$ denotes significance at $1 \%,{ }^{* *}$ at $5 \%,{ }^{*}$ at $10 \%$.

Tax1 CR denotes the first tax period in the CR, 2001-2003, Tax2 CR, 2004, Tax3 CR denotes 2005 and serves as benchmark for the Czech Republic (omitted from the regression).

Tax1 SR denotes the first tax period in the SR, 2001, Tax3 SR the last one, 2004. Tax2 SR denotes the period 2002-2003 and serves as a benchmark (omitted from the regression). See Table 1 for details.

the results from probit random effects, because the results did not differ significantly and probit is used for Heckman's selection correction. ${ }^{21}$

The results summarized in Table 4 illustrate that there are significant differences between the two countries: there is strong support for Hypothesis 3, that large companies are more active in the Czech Republic, since both the number of employees and sales have a positive impact on participation. In the Slovak Republic, the results are weaker and mixed: sales have a positive impact on sponsoring, and

${ }^{21}$ Results from the other estimations are available on request. 
the number of employees has a positive impact on giving participation. There is a strong difference also in Hypothesis 6, on the international level of operations: we observe higher giving participation of local firms in the Czech Republic, while in Slovakia companies on the international level participate more often in both sponsoring and giving. Interestingly, we do not find strong support for Hypothesis 4 , that foreign firms are more active: we observe only weak support for the hypothesis in Czech giving. The remaining results are either not significant or even negative, such as sponsoring participation in Slovakia. In both countries we observe that firms in the capitals are less active in philanthropy (Hypothesis 7). This may be a sign of free-riding, since there is high concentration of companies and some expect that others will take care of philanthropy, or the anonymity of the city makes it difficult to establish partnerships. We do not observe any strong significant results for Hypothesis 5 (the role of industry).

Finally, we observe a strong positive time trend in participation in the Czech Republic, while this trend is missing in Slovakia. We observe no significant impact of changes in tax rates, contrary to our expectations, particularly in Slovakia (Hypothesis 1), although the missing growth in Slovakia offers partial support for the negative impact of these changes. ${ }^{22}$

\subsection{Expenditures on Philanthropy}

Tables 5 and 6 summarize the results from the main specifications for expenditures on sponsoring and giving. To account for potential selection bias we include among the explanatory variables Heckman's $\lambda$ obtained from the participation equations summarized in the previous section. As in the previous analysis we merge the two Czech samples and analyze Slovakia separately. We used the Hausman test to compare the suitability of fixed and random effects; the test rejected the null hypothesis of independence of firm-specific effects and the error term in both specifications. Thus, we estimated FEM, and the results are summarized in Table $5 .^{23}$ In order to test the hypotheses regarding the observed firm characteristics we estimated a random effects model on the residuals from the fixed effects regression as described in the methodology section above. The results of these estimations are summarized in Table $6 .^{24}$

The coefficients on Heckman's $\lambda$ are insignificant in Slovakia, i.e., selection bias does not present a major hurdle. Therefore, in the decomposition regression below we report results from the models without correcting for selection bias. ${ }^{25}$ The coefficients in the fixed effects model (FEM) specification are insignificant even though the explanatory power of the models is high (measured by the adjusted $R^{2}$ ). Therefore, we can conclude that neither sales (with the exception of giving in the Czech Republic) nor taxes have an effect on expenditures on philanthropy: We fail to sup-

\footnotetext{
${ }^{22}$ We suspect that corporate philanthropy in Slovakia has similar "potential" to grow as in the Czech Republic, due to the favorable economic evolution, GDP growth, and the development of infrastructure supporting corporate philanthropy as summarized in Section 4 above.

${ }^{23}$ We also tested for the suitability of panel data estimation versus stacked pooled data estimation; the test rejected pooled estimation.

${ }^{24}$ We provide results from the fixed and random effects only. The results from the control treatments (interval regression, seemingly unrelated regression) did not differ significantly and are available on request.

${ }^{25}$ We do not provide results from the fixed effect estimation as they are similar to those provided.
} 
Table 5 Expenditures, FEM with Heckman's Correction

\begin{tabular}{|c|c|c|c|c|}
\hline & \multicolumn{2}{|c|}{ Sponsoring } & \multicolumn{2}{|c|}{ Giving } \\
\hline & CR & SR & CR & SR \\
\hline Sales log & $\begin{array}{c}0.41 \\
(0.28)\end{array}$ & $\begin{array}{l}-0.06 \\
(0.26)\end{array}$ & $\begin{array}{c}0.45^{\star \star *} \\
(0.16)\end{array}$ & $\begin{array}{c}0.03 \\
(0.42)\end{array}$ \\
\hline Year & $\begin{array}{c}0.08 \\
(0.07)\end{array}$ & $\begin{array}{c}0.09 \\
(0.08)\end{array}$ & $\begin{array}{c}0.06 \\
(0.06)\end{array}$ & $\begin{array}{l}-0.05 \\
(0.16)\end{array}$ \\
\hline Tax1 CR & $\begin{array}{c}0.03 \\
(0.17)\end{array}$ & & $\begin{array}{l}-0.17 \\
(0.21)\end{array}$ & \\
\hline Tax2 CR & $\begin{array}{c}0.09 \\
(0.14)\end{array}$ & & $\begin{array}{l}-0.001 \\
(0.16)\end{array}$ & \\
\hline Tax1 SR & & $\begin{array}{c}0.22 \\
(0.16)\end{array}$ & & $\begin{array}{c}0.15 \\
(0.31)\end{array}$ \\
\hline Tax3 SR & & $\begin{array}{l}-0.17 \\
(0.17)\end{array}$ & & $\begin{array}{c}0.06 \\
(0.28)\end{array}$ \\
\hline Inv. Mills & $\begin{array}{l}-1.18^{*} \\
(0.7)\end{array}$ & $\begin{array}{l}-2.02 \\
(1.61)\end{array}$ & $\begin{array}{l}-1.18^{* * *} \\
(0.42)\end{array}$ & $\begin{array}{l}-1.38 \\
(0.99)\end{array}$ \\
\hline Constant & $\begin{array}{c}1.27 \\
(3.11) \\
\end{array}$ & $\begin{array}{c}4.73 \\
(3.49) \\
\end{array}$ & $\begin{array}{c}0.63 \\
(1.77) \\
\end{array}$ & $\begin{array}{c}3.94 \\
(5.18) \\
\end{array}$ \\
\hline Adj. $R$ & 0.59 & 0.9 & 0.67 & 0.76 \\
\hline No. of obs. & 1062 & 312 & 1183 & 229 \\
\hline
\end{tabular}

Notes: Standard errors are in parentheses.

${ }^{* * *}$ denotes significance at $1 \%,{ }^{* *}$ at $5 \%,{ }^{*}$ at $10 \%$.

Table 6 Expenditures, Decomposition of Firm Effects

\begin{tabular}{|c|c|c|c|c|c|c|}
\hline & \multicolumn{3}{|c|}{ Sponsoring } & \multicolumn{3}{|c|}{ Giving } \\
\hline & CR & SR & SR 2 & CR & SR & SR 2 \\
\hline $\begin{array}{l}\text { Number } \\
\text { of employees }\end{array}$ & $\begin{array}{l}-0.09 \\
(0.12)\end{array}$ & $\begin{array}{c}0.25 \\
(0.27)\end{array}$ & $\begin{array}{c}0.25 \\
(0.27)\end{array}$ & $\begin{array}{l}-0.57^{* \star *} \\
(0.16)\end{array}$ & $\begin{array}{r}0.54^{*} \\
(0.28)\end{array}$ & $\begin{array}{r}0.54^{*} \\
(0.28)\end{array}$ \\
\hline Manufacturing & $\begin{array}{c}0.3 \\
(0.22)\end{array}$ & $\begin{array}{c}0.72 \\
(0.52)\end{array}$ & $\begin{array}{c}0.72 \\
(0.52)\end{array}$ & $\begin{array}{l}-0.02 \\
(0.29)\end{array}$ & $\begin{array}{l}-0.98^{* *} \\
(0.42)\end{array}$ & $\begin{array}{l}-1.00^{* *} \\
(0.42)\end{array}$ \\
\hline Retail & $\begin{array}{l}-0.07 \\
(0.27)\end{array}$ & $\begin{array}{c}0.57 \\
(0.59)\end{array}$ & $\begin{array}{l}0.58 \\
(0.59)\end{array}$ & $\begin{array}{l}-0.54^{*} \\
(0.31)^{*}\end{array}$ & $\begin{array}{l}-0.81^{*} \\
(0.45)\end{array}$ & $\begin{array}{l}-0.84^{*} \\
(0.44)\end{array}$ \\
\hline Level of operation & $\begin{array}{l}0.42^{* * *} \\
(0.14)\end{array}$ & $\begin{array}{l}-0.61^{*} \\
(0.33)\end{array}$ & $\begin{array}{l}-0.6^{*} \\
(0.33)\end{array}$ & $\begin{array}{l}-0.26 \\
(0.18)\end{array}$ & $\begin{array}{l}-0.34 \\
(0.24)\end{array}$ & $\begin{array}{l}-0.34 \\
(0.23)\end{array}$ \\
\hline Foundation & $\begin{array}{l}0.58^{* *} \\
(0.24)\end{array}$ & $\begin{array}{l}-0.001 \\
(0.96)\end{array}$ & $\begin{array}{l}-0.007 \\
(0.95)\end{array}$ & $\begin{array}{l}0.97^{\star * *} \\
(0.37)\end{array}$ & $\begin{array}{l}-0.64 \\
(0.81)\end{array}$ & $\begin{array}{l}-0.64 \\
(0.81)\end{array}$ \\
\hline Capital & $\begin{array}{l}-0.12 \\
(0.27)\end{array}$ & $\begin{array}{l}-0.61 \\
(0.48)\end{array}$ & $\begin{array}{l}-0.61 \\
(0.48)\end{array}$ & $\begin{array}{r}0.56^{*} \\
(0.31)\end{array}$ & $\begin{array}{l}1.09 \\
(0.94)\end{array}$ & $\begin{array}{c}0.94 \\
(0.85)\end{array}$ \\
\hline Foreign own & $\begin{array}{l}-0.45 \\
(0.30)\end{array}$ & $\begin{array}{c}1.36 \\
(0.98)\end{array}$ & $\begin{array}{c}1.15 \\
(0.97)\end{array}$ & $\begin{array}{l}-1.11^{\text {** }} \\
(0.45)\end{array}$ & $\begin{array}{l}-1.72^{*} \\
(0.99)\end{array}$ & $\begin{array}{l}-1.46 \\
(0.91)\end{array}$ \\
\hline Mixed own & $\begin{array}{l}-0.26 \\
(0.26)\end{array}$ & $\begin{array}{l}-0.2 \\
(0.52)\end{array}$ & $\begin{array}{l}-0.23 \\
(0.52)\end{array}$ & $\begin{array}{l}-0.28 \\
(0.36)\end{array}$ & $\begin{array}{l}-0.57 \\
(0.39)\end{array}$ & $\begin{array}{l}-0.8^{*} \\
(0.41)\end{array}$ \\
\hline Foreign 2004 & & & $\begin{array}{l}0.71^{* * *} \\
(0.2)\end{array}$ & & & $\begin{array}{l}-0.8 \\
(0.58)\end{array}$ \\
\hline Mixed 2004 & & & $\begin{array}{l}0.33^{\star * *} \\
(0.11)\end{array}$ & & & $\begin{array}{c}0.67 \\
(0.49)\end{array}$ \\
\hline Domestic 2004 & & & $\begin{array}{l}-0.15 \\
(0.14)\end{array}$ & & & $\begin{array}{l}-0.13 \\
(0.15)\end{array}$ \\
\hline CR II & $\begin{array}{l}-2.03^{* * *} \\
(0.21)\end{array}$ & & & $\begin{array}{l}-2.5^{\star * *} \\
(0.24)\end{array}$ & & \\
\hline Constant & $\begin{array}{l}-0.62^{* * *} \\
(0.49)\end{array}$ & $\begin{array}{c}0.48 \\
(0.93)\end{array}$ & $\begin{array}{c}0.51 \\
(0.95)\end{array}$ & $\begin{array}{l}2.07^{* * *} \\
(0.6)\end{array}$ & $\begin{array}{c}0.76 \\
(0.78)\end{array}$ & $\begin{array}{c}0.82 \\
(0.79)\end{array}$ \\
\hline
\end{tabular}

Notes: Standard errors are in parentheses.

${ }^{* * *}$ denotes significance at $1 \%,{ }^{* *}$ at $5 \%,{ }^{*}$ at $10 \%$, respectively.

SR 2 column provides results from additional specification developed to examine the impact of the legislative changes in Slovakia in 2004 on different ownership forms. 
port Hypothesis 1, as there is no significant decline in giving in Slovakia after 2004 (the coefficient on $\operatorname{Tax} 3 S R$ ). The only evidence we have to this end is the missing growth of participation (contrary to the Czech case) described in the previous section. We also fail to support Hypothesis 2, a different impact of taxes on sponsoring and giving, or a difference between the two countries. This result is caused by two facts: many of the relevant determinants were captured in the participation decision and the main explanatory power for the expenditure decision is in the firm-specific characteristics, which are observable only in the subsequent regressions on the residuals. ${ }^{26}$ Results from these regressions follow.

Size, as measured by the number of employees, was found to have no effect on expenditures on sponsoring. In giving, however, we observe opposite effects in the two countries: in the Czech Republic small firms give more than firms with many employees, but the opposite is true in Slovakia. The negative impact of size in the Czech Republic indicates an increase in the importance of philanthropy among small companies, a trend that is not present in Slovakia yet. The finding that small firms give more in terms of their profits than large companies is in line with the results of Guthrie et al. (2008), who show a larger impact of smaller firms. Generally, the wisdom that large firms spend more on charity and philanthropic activities has been successfully questioned by several reports from mature markets. ${ }^{27}$ However, the overall effect of small versus large corporations is still not completely answered: while we found that small corporations in the Czech Republic give more in relative terms, we did not analyze the total (direct and indirect) impact of large corporations on philanthropy and corporate giving. It is quite plausible that large firms give smaller amounts in terms of their profits but their impact is important as they are visible and through their visibility they show that corporate philanthropy is an important and valuable activity.

Ownership (Hypothesis 4) has different impacts on sponsoring and giving: while it does not affect expenditure on sponsoring, foreign-owned firms spend significantly less on giving. These results fail to support Hypothesis 4, that foreign firms are the leaders in philanthropy. Moreover, foreign-owned firms are more profit driven, as observed in an additional test on the Slovak sample. We added interaction terms between the year 2004 and ownership among the explanatory variables because the 2004 change was expected to have the strongest effect on expenditures. The results (SR 2, the third column of Table 6 ) support this expectation. While the domestic firms did not change their behavior significantly in 2004, the foreign firms did: we observe an increase in sponsoring expenditures; the effect on giving is negative but not significant. This result suggests that sponsoring and giving are substitutes and profit-oriented firms shift towards the cheaper one.

We observe no difference in spending on sponsoring among industries. Firms in retail, and in Slovakia also those in manufacturing, spend less on giving. Thus, we partially support Hypothesis 5, that firms in services give most (though they give

\footnotetext{
${ }^{26}$ When looking at the results it is necessary to keep in mind that we only analyze the information for firms that gave or sponsored (in at least one year) and reported the information on their sales.

${ }^{27}$ For example, a large research report by Hall et. al. (2008) shows that the total value of contributions from large corporations as a percentage of pre-tax profits is actually lower than that of the broader business community (median value of $1.0 \%$ vs. $1.25 \%$, respectively). The same relationship is found when the percentage of total revenues is used (median of $0.06 \%$ compared to $0.63 \%$ ).
} 
least often), followed by firms in retail and manufacturing. The difference between sponsoring and giving may result from their different nature, giving being a result of stakeholders' pressure and their closeness to the company, and sponsoring being aimed at attracting customers, similarly to advertising.

The level of operation (Hypothesis 6) matters only for expenditures on sponsoring. In the Czech Republic, regionally operating firms spend more on sponsoring, but in Slovakia they spend the least. We observe no differences in giving. The absence of a difference in expenditures between firms at the international and local level is positive, though we have to keep in mind that local firms in Slovakia do participate significantly less often.

Regarding Hypothesis 7, we observe that firms in Prague spend more on giving than firms in other regions. We observe no other difference. We are not able to identify the specific motives for such behavior. One possible reason is a positive correlation between profitability and location in Prague. As we do not control for profits in the specification, location might capture some of this effect.

We observe that the levels in the second sample are significantly below the levels in the old one. The Chow test of similarity of coefficients failed to reject the hypothesis of no difference; the only difference is in the level captured by $C R I I$. This is possibly caused by the non-random choice of some participants in the original Czech survey - the important donors. Even though the additional companies were chosen so that the sample would become representative, the inclusion of these major donors may cause upward bias in the level of giving.

To address the problem of the bad structure of the first interval in the original Czech sample we estimated the same specifications using common intervals. In addition, we did not use the middle point of the first interval but instead used the average of the observations obtained from the additional samples. This estimation was used to observe the effect of the merging of the first interval. The results from this control treatment did not differ significantly from the results presented above, with one exception: the coefficients of the two tax dummies (Tax2_CR, Tax1_SR) were significant. ${ }^{28}$ This difference suggests that merging the intervals may emphasize differences that would otherwise remain unobservable. On the other hand, the large intervals were not created with any theory in mind, thus the observed effect is likely to be artificial. Choosing a different merging of intervals would probably lead to a different result. Nevertheless, the results obtained offer some support for the hypothesis that there is a difference in the motivation for sponsoring and giving, sponsoring being motivated more strongly by the maximization of profits than giving.

\section{Conclusion}

In this study we analyzed the corporate philanthropic behavior of firms in two transition countries, the Czech Republic and Slovakia, using survey data on 739 firms in the Czech Republic and 152 in Slovakia. The results reveal that despite the long common history of the two countries there are significant differences in the current philanthropic behavior of firms. Namely, firms in the Czech Republic gave more often and significantly more than firms in Slovakia. In addition, giving in Slovakia is more

${ }^{28}$ The results of this estimation are available on request. 
prevalent among large firms operating on the international level, while in the Czech Republic smaller, regional firms also participate. These differences between the countries seem to be caused by differences in profitability, reinforced by missing "leaders" in Slovakia, i.e., large Slovak firms give less than large Czech firms. The differences in sponsoring behavior are smaller.

One of the major questions of this study was the impact of taxes: did decreasing corporate tax rates affect corporate philanthropy? If we looked only at the significance of tax variables the answer would be no, none of the changes had a significant impact on either sponsoring or giving. According to Navarro's interpretation (Navarro, 1988) this means that corporate philanthropy is motivated predominantly by the maximization of managerial utility and not by profit maximization. However, these results need to be considered with caution because the changes in tax rates in the Czech Republic were rather minor. In Slovakia, the differences were bigger, in particular the tax change in 2004. The fact that the change in 2004 did not have any negative impact on the level of giving suggests that the tax legislation seems not to have an impact on the philanthropic behavior of firms. But we believe it is important to take into consideration that contrary to the Czech Republic, philanthropic engagement or expenditures in Slovakia did not grow in the studied period despite strong economic growth. Thus, the potential positive growth was prevented by simultaneous changes in the tax legislation.

To further evaluate the impact of the tax change in 2004 in Slovakia we analyzed it separately for firms with different ownerships. We observed that while the change had no effect on firms with domestic or mixed ownership, it had a significant effect on firms with foreign owners, which shifted their support to sponsoring in 2004, suggesting that foreign firms are more profit-motivated than domestic ones. In general, though, we did not find support for the hypothesis that firms with foreign capital give or sponsor more. We observed that foreign-owned firms in the Czech Republic give more often, but their expenditures are below those of other firms.

While in the Czech Republic we observe significant growth in participation in both sponsoring and giving, participation in Slovakia has remained stable, despite significant economic growth and activities in support of corporate philanthropy. The participation of foreign-owned firms in Slovakia is significantly below the participation of domestic firms in sponsoring. Their expenditures on sponsoring are similar, but they are significantly below those of domestic firms in giving. We failed to support our hypothesis regarding higher engagement of firms in services, with the exception of sponsoring in the Czech Republic. Their expenditures on giving, however, are the highest in both countries. This may result from the fact that the profitability of firms in services is the lowest when compared to other industries, having a negative effect on participation. On the other hand, once they start to engage in philanthropy, possibly because of their close relationships with stakeholders, the firms tend to give more. This feature may be a sign of growing corporate social responsibility in the region. 


\section{REFERENCES}

Abzug R, Webb NJ (1997): Rational and extra-rational motivations for corporate giving: Complementing economic theory with organization science. New York Law School Law Review, 41(3-4): 1035-1058.

Bena J, Hanousek J (2008): Rent Extraction by Large Shareholders Evidence Using Dividend Policy in the Czech Republic? Finance a úverr-Czech Journal of Economics and Finance, 58(3):106-130.

BLF CR (2004): Společenská odpovědnost firem. Kompletní průvodce tématem a závěry průzkumu v $\check{C} R$. (Corporate social responsibility. Complete guide through the topic and conclusions from a survey). Business Leaders Forum, Prague, February 2004.

BLF SR (2005): Spoločenská zodpovednost firiem. Vnímanie obyvatelmi Slovenska. (Corporate social responsibility. Perception by citizens of Slovakia.) Business Leaders Forum, Bratislava, Autumn 2005. http://www.partnerstva.sk/buxus/docs/PONTIS_Prieskum_CSR_Verejnost_2005.pdf

Boatsman JR, Gupta S (1996): Taxes and corporate charity: Empirical evidence from micro-level panel data. National Tax Journal, 49(2):193-213.

Brammer S, Pavelin S (2005): Corporate Community Contributions in the United Kingdom and the United States. Journal of Business Ethics, 56:15-26.

Bussard A, Markuš M, Bunčák M, Marček E (2005): Spoločensky zodpovedné podnikanie. Prehl’ad základných princípov a príkladov. (Socially responsible entrepreneurship. An overview of basic principles and examples.) Foundation Integra, Foundation Pontis, PANET, Bratislava.

Campbell D, Moore G, Metzger M (2002): Corporate philanthropy in the U.K. 1985-2000: Some empirical findings. Journal of Business Ethics, 39(1/2):29-41.

CERGE-EI (2004): Czech Republic 2003/2004, Entering the EU. Prague, CERGE EI.

Clotfelter ChT (1985): Federal tax policy and charitable giving. Chapter 5: Corporate contributions, NBER Monograph. The University of Chicago Press, Chicago and London.

DF (2004): Jak jsme na tom s firemni filantropií v Českě republice? Výsledky výzkumu firemní filantropie. (How do we stand in the corporate philanthropy in the Czech Republic? Results of corporate philanthropy study.) Donors Forum, Prague 2004. See also:

http://aa.ecn.cz/img_upload/65636e2e7a707261766f64616a737476/firemnifilantrop_vyzkum.doc

Estrin S, Hanousek J, Kočenda E, Svejnar J (2009): Effects of Privatization and Ownership in Transition Economies. Journal of Economic Literature, 47(3):699-728.

Fidrmuc J, Gerxhani K (2005): Formation of social capital in Central and Eastern Europe: Understanding the gap vis-à-vis developed countries. William Davidson Institute Working Paper, no. 766, April 2005.

Fry LW, Keim GD, Meiners RE (1982): Corporate contributions: Altruistic of for-profit? Academy of Management Journal, 25(1):94-106.

Galaskiewicz J, Colman MS (2006): Collaboration between corporations and nonprofit organizations. In: Steinberg R, Powell WW (Eds.): The Nonprofit Sector: A Research Handbook. 2nd edition. New Haven, CT: Yale University Press.

Green WH (1993): Econometric Analysis. 2nd edition. Macmillan Publishing Company, New York.

Guthrie D, Arum R, Roksa J, Damaske S (2008): Giving to local schools: Corporate philanthropy, tax incentives, and the ecology of need. Social Science Research, 37(3):856-873.

Hall MH et. al. (2008): Corporate community investment practices, motivations and challenges: findings from the Canada Survey of Business Contributions to Community. Toronto, Imagine Canada.

Hanousek J, Palda F (2004): Quality of Government Services and the Civic Duty to Pay Taxes in the Czech and Slovak Republics and other Transition Countries. Kyklos, 57(2):237-252.

Hanousek J, Palda F (2003): Tax Evasion in the Czech and Slovak Republics: A Tale of Twins. In: Belev B (Ed.): The Informal Economy in Transition Countries: Measurement, and Implications for Policy. World Bank and the Bertelsman Group, Sofia. 
Hanousek J, Kočenda E (2008): Potential of the State to Control Privatized Firms. Economic Change and Restructuring, 41(2):167-186.

Hanousek J, Kočenda E, Svejnar J (2007): Origin and Concentration: Corporate Ownership, Control and Performance in Firms after Privatization. Economics of Transition, 15(1):1-31.

Hanousek J, Kočenda E, Svejnar J (2009): Divestitures, Privatization and Corporate Performance in Emerging Markets. Economics of Transition, 17(1):43-73.

Helland E, Smith JK (2003): Corporate philanthropy. Manuscript, November 22, 2003, http://ssrn.com/abstract=472161.

Ilko I (2004): Philanthropy in the U.S.: Lessons and experiences for the Ukrainian emerging philanthropic sector. Manuscript, http://www.pubpol.duke.edu/centers/civil/papers/ilko.pdf.

IVO (2002): Slovensko 2002. Súhrnná správa o stave spoločnosti II. (Slovakia 2002, Report on the state of society II.) Eds.: Kollar M, Meseznikov G. Institute for public affairs (IVO), Bratislava .

Jankech P (2002): Analysis of the Effect of the Charitable Contribution Deduction on Charitable Giving within the Profit and Utility Maximizing Frameworks. Thesis, Central European University, Budapest.

King K, Tchepournyhk M (2004): Corporate giving in the U.S.A.: A model for meeting Russia's expanding social needs? International Journal of Nonprofit and Voluntary Sector Marketing, 9(3): $218-228$.

Kivilo A (2005): Corporate support for the arts in a small country in transition: The experience and motivation factors for corporate patronage and sponsorship in Estonia. Manuscript, http://www.hec.ca/aimac2005/PDF_Text/Kivilo_Anu.pdf.

Lízal L, Kočenda E (2002): State of corruption in transition: case of the Czech Republic. Emerging Markets Review, (2):137-159.

Marček E, Dluhá M (2002): Podniky a neziskové organizácie, Analýza vzájomnej spolupráce na Slovensku. (Firms and nonprofit organizations, An analysis of mutual cooperation in Slovakia.) PANET, Bratislava.

Múčka F (2004): Čo ubližuje firemnej charite? (What harms corporate charity?) Trend, (51).

Navarro P (1988): Why do corporations give to charity? The Journal of Business, 61(1):65-93.

NDS (2005): $2 \%$ dane právnických osob-záverečná správa. (2\% of the taxes of legal persons, final report.) Prepared by FOCUS for NDS (Foundation of children of Slovakia).

Velšic M (2004): Ekonomické elity a korporativna filantropia na Slovensku. (Economic elites and corporate philanthropy in Slovakia.) Institute for public affairs (IVO), Bratislava, September 2004.

WB (2004): Overview of the results of corporate social responsibility survey in Slovakia. World Bank DevComm-SDO, www.blf.sk.

Wooldridge JM (2002): Econometric Analysis of Cross Section and Panel Data. MIT Press.

Wooldridge JM (2003): Cluster-Sample Methods in Applied Econometrics. The American Economic Review, 93(2):133-138. 